\title{
松浦火力発電所貯炭場地盤改良の設計・施工 \\ DESIGN AND CONSTRUCTION OF FOUNDATION IMPROVEMENT OF COAL STORAGE YARD AT MATSUURA THERMAL POWER PLANT
}

\author{
平川義行*・篠原淑 郎**・宮入寛 雄*** \\ By Yoshiyuki HIRAKAWA, Yoshio SHINOHARA and Hiroo MIYAIRI
}

\begin{abstract}
The Matsuura thermal power plant is a joint undertaking between Kyushu Electric Power Company and Electric Power Development Company. The formar will install two $700 \mathrm{MW}$ units and the latter will install two $1000 \mathrm{MW}$ coal fired units, having a combined installed capacity of $3400 \mathrm{MW}$ which will be the largest coal fired plant in Japan.

This report shows the outline of design and construction of foundation improvement works for the coal storage yard. The sand compaction pile method was adopted to reduce the settlement of coal yard foundation. And the cement stabilization was carried out to improve the surface soil for the stability of stockpile.
\end{abstract}

Keywords : coal storage yard, sand compaction, cement stabilization

\section{1. まえがき}

九州電力 (株) と電源開発 (株) は, 西日本の電力安定 供給をはかり, あわせて, エネルギ一源の多様化を積極 的に進めるため, 長崎県松浦市に輸入石炭を燃料とする 大規模火力発電所である松浦火力発電所を建設中であ る. 当発電所は, 最終的に九州電力が出力 70 万 $\mathrm{kW} \times 2$ 基, 電源開発が 100 万 $\mathrm{kW} \times 2$ 基を設備する計画であり, 両社の共同立地方式により 1985 年に着工し, 土木工事 はそれぞれの 2 号機分の一部を除きほぼ完了している. すでに九州電力 1 号機については 1989 年 6 月に営業運 転を開始しており, 電源開発 1 号機も 1990 年 7 月に運 転開始の予定である.

発電所位置を図一1に，全体配置計画を図一2に示す. 写真一1は, 電源開発 (株) 松浦火力発電所の建設状 況を示す.

発電所本館, 貯炭場, 環境対策設備等はそれぞれ両社 の専有設備であるが, 揚炭栈橋, ユーティリティ岸壁,

* 正会員 電源開発 (株) 松浦火力建設所長 ( ( 859-45 長崎県松浦市志佐町白浜免)

** 正会員 (株) 鴻池組 (前・松浦火力建設所長) ( ₹101 千代田区神田駿河台 2-3-11)

*** 正会員 電源開発 (株) 松浦火力建設所長代理 ( \% 859-45 長崎県松浦市志佐町白浜免)
灰捨場等, 機能を共有できるものは極力両社の共有設備 として計画し, 建設費を両社の出力比で分担することと して，経済的な全体配置を行った.

主要な土木構造物として, 10 万 DWT 級石炭船 $\times 2$

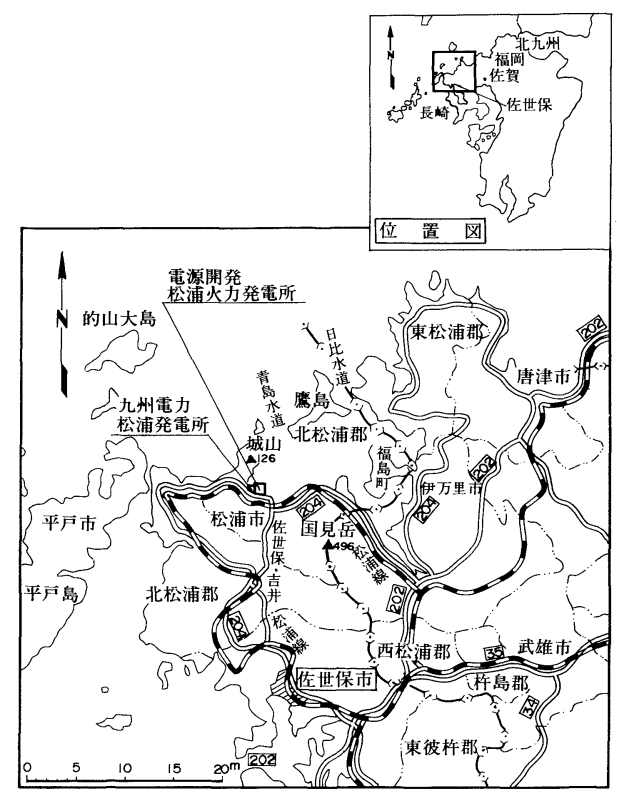

図一1 松浦火力発電所位置図 


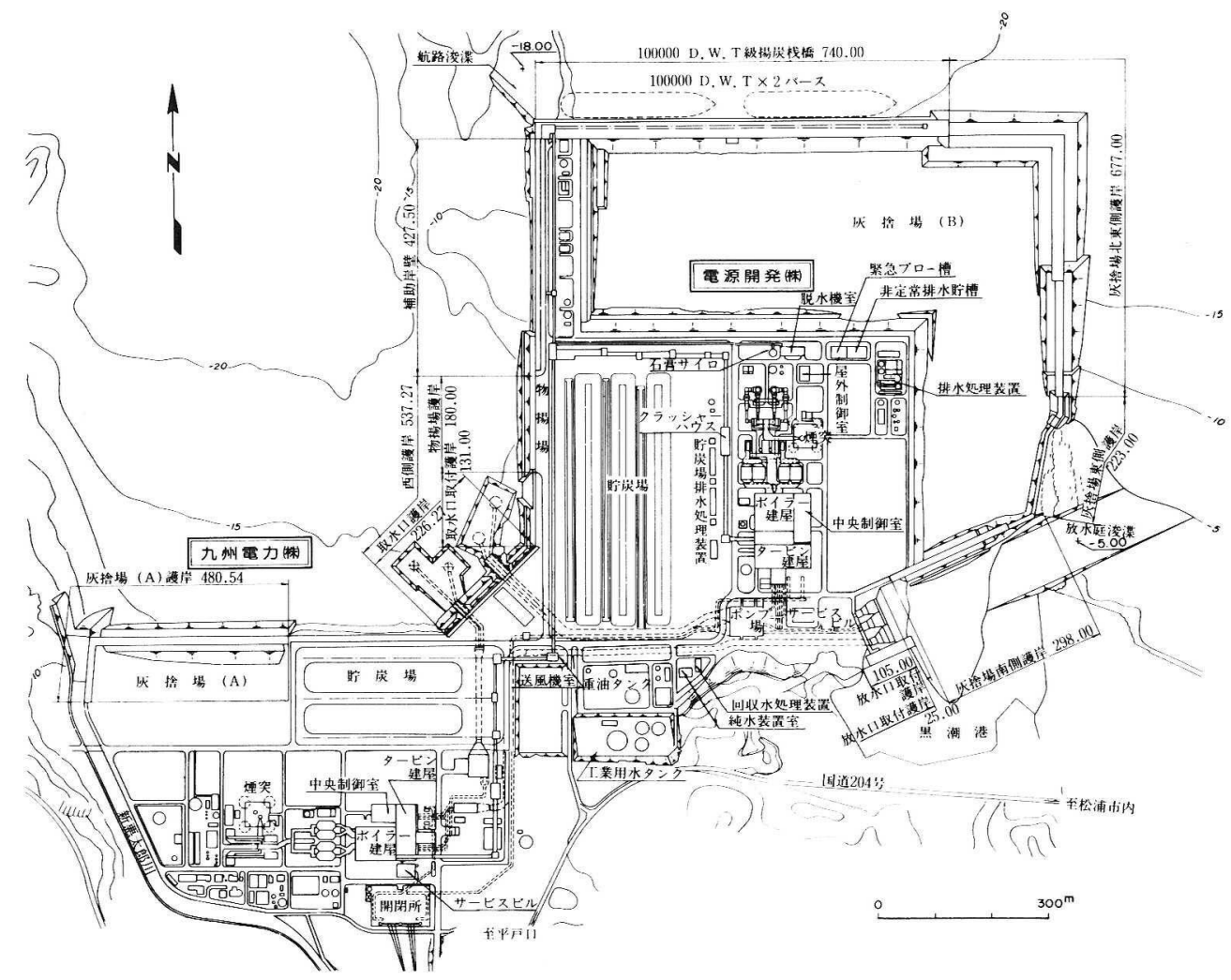

図 2 全体配置図 (1 号機運転開始時点)

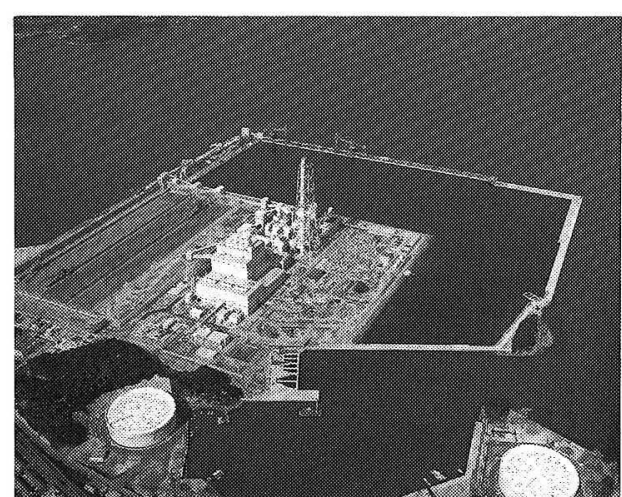

写真一1 建設中の松浦火力発電所

バースの揚炭栈橋（延長 $740 \mathrm{~m}$ ），全周約 $3.3 \mathrm{~km}$ の灰捨 場護岸，電発専有設備である 100 万 $\mathrm{kW} \times 2$ 基のための 冷却水取放水設備, 面積約 14 万 $\mathrm{m}^{2}$ の貯炭場等がある.

当地点の地質は, 岩盤の上に全般的に軟弱な粘性土層 および砂質土層が堆積しており，上層は $N$ 值が $0 \sim 3$, 一軸圧縮強度が $0.05 \sim 0.4 \mathrm{kgf} / \mathrm{cm}^{2}$ 程度という非常に軟 弱な地層である。したがって, 揚炭栈橋ならびに護岸部 では, 締固め砂杭工法により, これら軟弱地盤の改良を 行っており, 改良面積は約 $227000 \mathrm{~m}^{2}$ に達している.
本報告は，海域部における大量の砂杭の施工実績と， 各種計測結果 ${ }^{1,2)}$ を踏まえたうえで, 護岸工事に引き続 き施工した貯炭場埋立地盤部の地盤改良の設計ならびに 施工管理について述べるものである.

\section{2. 貯炭場基礎の設計}

貯炭場の計画諸元を表一 1 に，計画平面を図一 3 に示 す.

当面， 2 号機運転開始までの間は，石炭の山積みの列 (以下，貯炭パイルと称す) を 3 列で運用する計画であ り, 石炭の受入・払出し用に, スタッカー 1 基, リクレー マ 1 基, スタックリクレーマ 1 基を設置する.

貯炭場面積の約 $2 / 3$ は, 護岸工事に引き続き行った 1987 年 2 月からの埋立てにより造成した土地である.

埋立ては 1988 年 3 月に完了, 工程上の制約もあって その後直ちに貯炭場基礎工事にとりかかることとなり， 大規模な地盤改良が必要となった。

貯炭場部の埋立てに要した土量は, 全体で約 36 万 $\mathrm{m}^{3}$ であり，その内訳は，海砂 11 万 $\mathrm{m}^{3}$ ，ぼた 11 万 $\mathrm{m}^{3}$ ，現 場内掘削土 (以降, 流用土と称する) 11 万 $\mathrm{m}^{3}$, その他 3 万 $\mathrm{m}^{3}$ である.ここで,「ぼた」とは, 石炭の採掘に伴っ て地中から掘り出される粗悪な石炭, 頁岩, 砂岩などの 
砕屑物の総称であり，ぼた山として集積されたものが， 長崎県だけで約 150 か所，約 3700 万 $\mathrm{m}^{3}$ あるとされて いる3 ${ }^{3)}$ 当地点では，これらの投棄されたぼたを埋立て 材として利用することとし，海上約 $13 \mathrm{~km}$ の距離にあ る伊万里湾奥のぼた山より，貯炭場以外の埋立ても含め て，全体で約 37 万 $\mathrm{m}^{3}$ のぼたを運搬，投入した.

また，埋立て材として用いた海砂は，海上約 $50 \mathrm{~km}$ の採取地より搬入したものであり，全体では約 35 万 $\mathrm{m}^{3}$ を使用した。

なお，これらの埋立材料の選定ならびに施工順序は， 工程上の制約および経済性を考慮して決めたものであ り，設計上の考慮は特に行っていない.

\section{（1）土質}

貯炭パイルおよびスタッカー, リクレーマ等の運炭機 械の基礎となる部分は, 前述のとおり, 平面的にその約 $2 / 3$ の部分が新規埋立地であり，代表的には，図一4の 縦断図に示すような地質構成となっている. 図中,「埋 立土」とあるのは，ぼたと流用土の混ざり合ったものを 表わしている.

貯炭場計画地点において工事開始前に行った地質調査 ボーリング 11 本のうちから，代表的な柱状図を図一5 に示すが，「碩混り土」とあるのが，埋立土（ぼた，流 用土）を表わしており，「砂」は，ボーリングNo.1に ついては在来の砂層を, ボーリング No. 2 については埋

\section{表-1＼cjkstart計画諸元}

\begin{tabular}{|c|c|c|}
\hline 貯孷場面棲 & \multicolumn{2}{|c|}{$138,000 \mathrm{~m}^{2}$} \\
\hline 貯炭パイル & & \\
\hline パイル数 & \multicolumn{2}{|c|}{4 パイル (3パイル) } \\
\hline 1 パイル当り & $\begin{array}{l}\text { 幅 } \\
\text { 蒿さ } \\
\begin{array}{l}16 \mathrm{~m} \\
\text { 長さ }\end{array} 450 \mathrm{~m}\end{array}$ & （底辺） \\
\hline 眝炭容量 & $\begin{array}{rrrrrr}4 & 8 & 0, & 0 & 0 & 0 \\
3 & 6 & 0, & 0 & 0 & 0\end{array}$ & $\begin{array}{lll}\mathrm{t} & 0 & \mathrm{n} \\
\mathrm{t} & 0 & \mathrm{n}\end{array}$ \\
\hline
\end{tabular}

注）（）内は 1 号機運転開始時点

\section{表一2 地層概要}

\begin{tabular}{|c|c|c|c|}
\hline \multicolumn{2}{|c|}{ 地 回 } & 層厚 $(\mathrm{m})$ & $\mathrm{N}$ 值 \\
\hline & 流用土 & $5.3 \sim 7.8$ & $3 \sim 6$ \\
\hline & ほ た & $3.4 \sim 8.2$ & $2 \sim 13$ \\
\hline 立 & 海秒 & $1.0 \sim 6.4$ & $3 \sim 16$ \\
\hline \multirow{2}{*}{$\begin{array}{l}\text { 堆 } \\
\text { 稑 }\end{array}$} & 抄留土 & $0.7 \sim 6.7$ & $3 \sim 10$ \\
\hline & 粘 性土 & $1.3 \sim 4.0$ & $4 \sim 6$ \\
\hline 岩 & $\begin{array}{l}\text { 杪岩 } \\
\text { ～頁岩 }\end{array}$ & - & $20 \sim 50$ \\
\hline
\end{tabular}

立てた海砂を表わしている.これらの調査から得られた 各土層の層厚と $N$ 值, 物理力学特性について, 表一 2 , 表一3に示す.

\section{（2）荷重条件}

貯炭パイル部は，石炭の積上げ高さ $16 \mathrm{~m}$ であり，上 載荷重として, $19.2 \mathrm{tf} / \mathrm{m}^{2}$ を考え, また, 下敷炭の施工 時および機械設備の維持補修作業用の車両通行荷重とし て T-20 荷重を考慮した。一方, 石炭の受入・払出し用 機械設備の基礎部（道床部と称する）は，スタックリク レーマ $(700 \mathrm{t} /$ 基) の作業時の輪荷重がレールおよび レール下部の砕石基礎を介して, 貯炭場地盤表面では $4.3 \mathrm{tf} / \mathrm{m}^{2}$ となる.

\section{（3）許容沈下量}

当貯炭場の設計にあたって，最も基本的な条件として 定めなければならなかった点は，沈下をどこまで許容す るかという点であり, 道床部については, 機械の走行安 定性を考慮して, 表一4に示すような許容值を設定した.

また，貯炭パイル部については，沈下を生ずることに よる直接的な影響は, (1)地表面付近の利用不可能部分の 石炭が増えるという点であるが，さらに，(2)パイル部が 大きく沈下することにより，貯炭場内に配置している盲 排水管, 排水側溝, 排水暗渠の勾配がとれない等の障害 を引き起こす可能性があること，また，(3)過大な沈下に よって引き起こされる地盤の側方変位により, 道床部の 水平変位量がレール真直度の許容值を越えるおそれがあ ること，が挙げられる。ここでは, (3)を第一の条件とし て考えることとし, Oteo の提案した側方変位に関する パラメーター $R$ と $H / B(H$ : 軟弱層の厚さ, $B$ : 載荷 盛土幅) の関係 ${ }^{4)} よ り$, 最大側方変位量 $\rho_{h \max }$ が, $H / B$

\section{表一3 原地盤の物理力学特性}

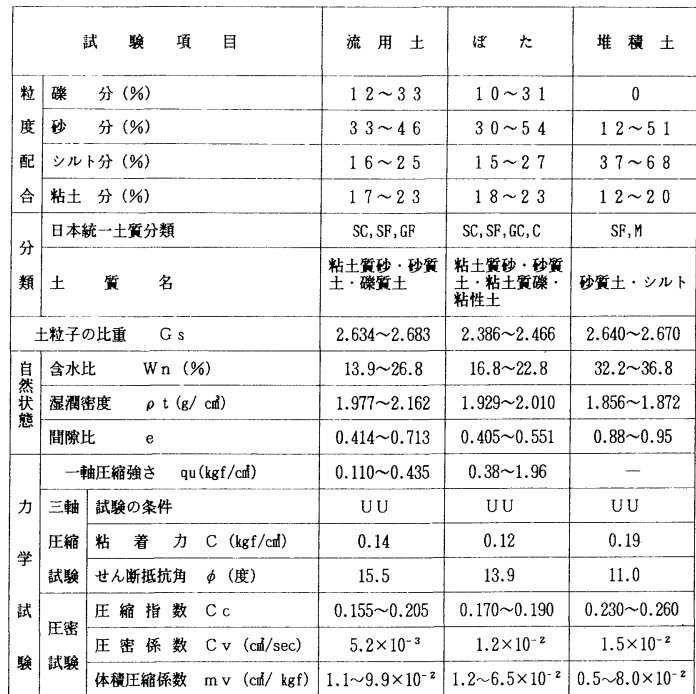



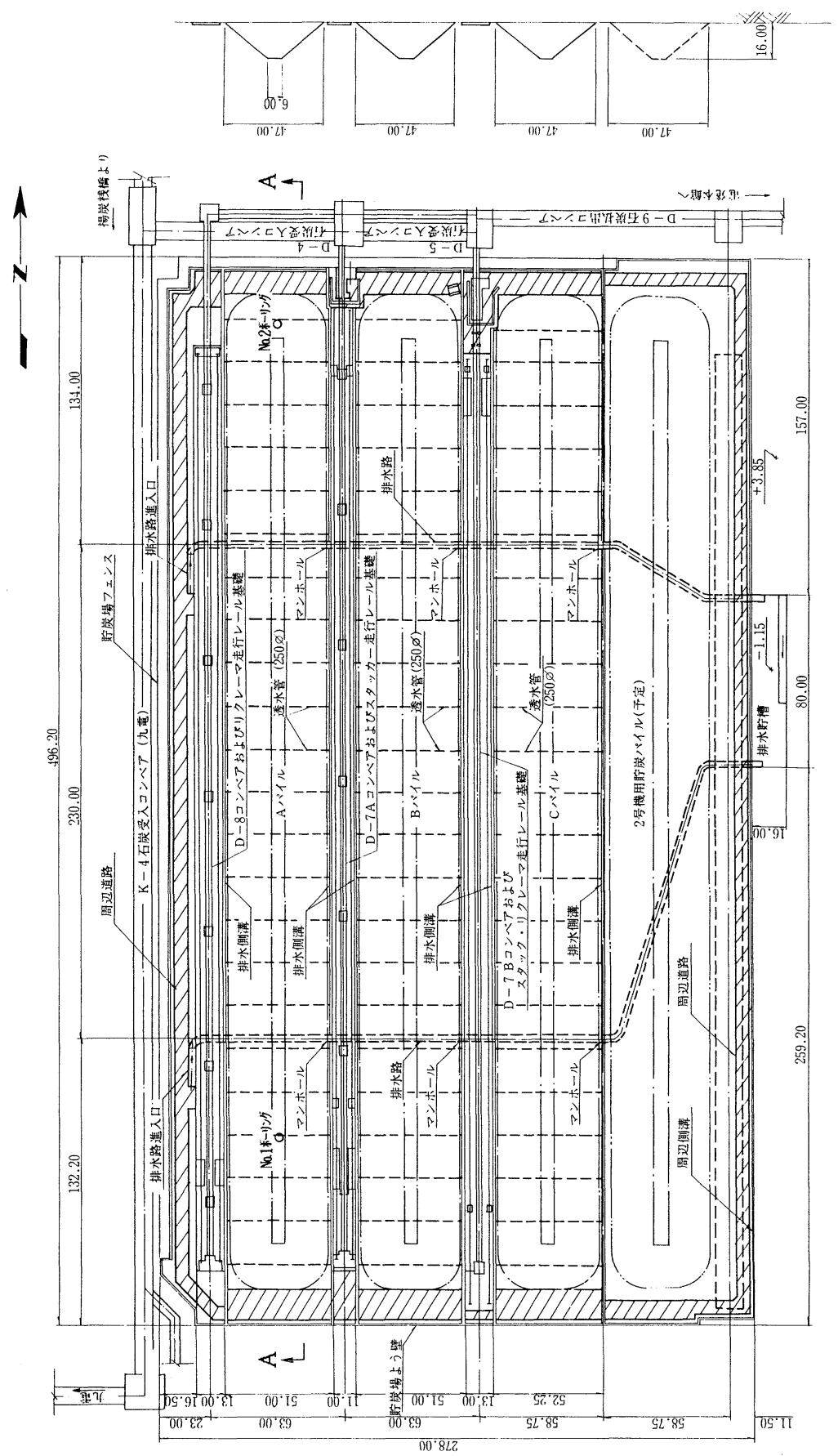

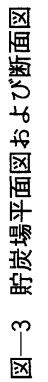



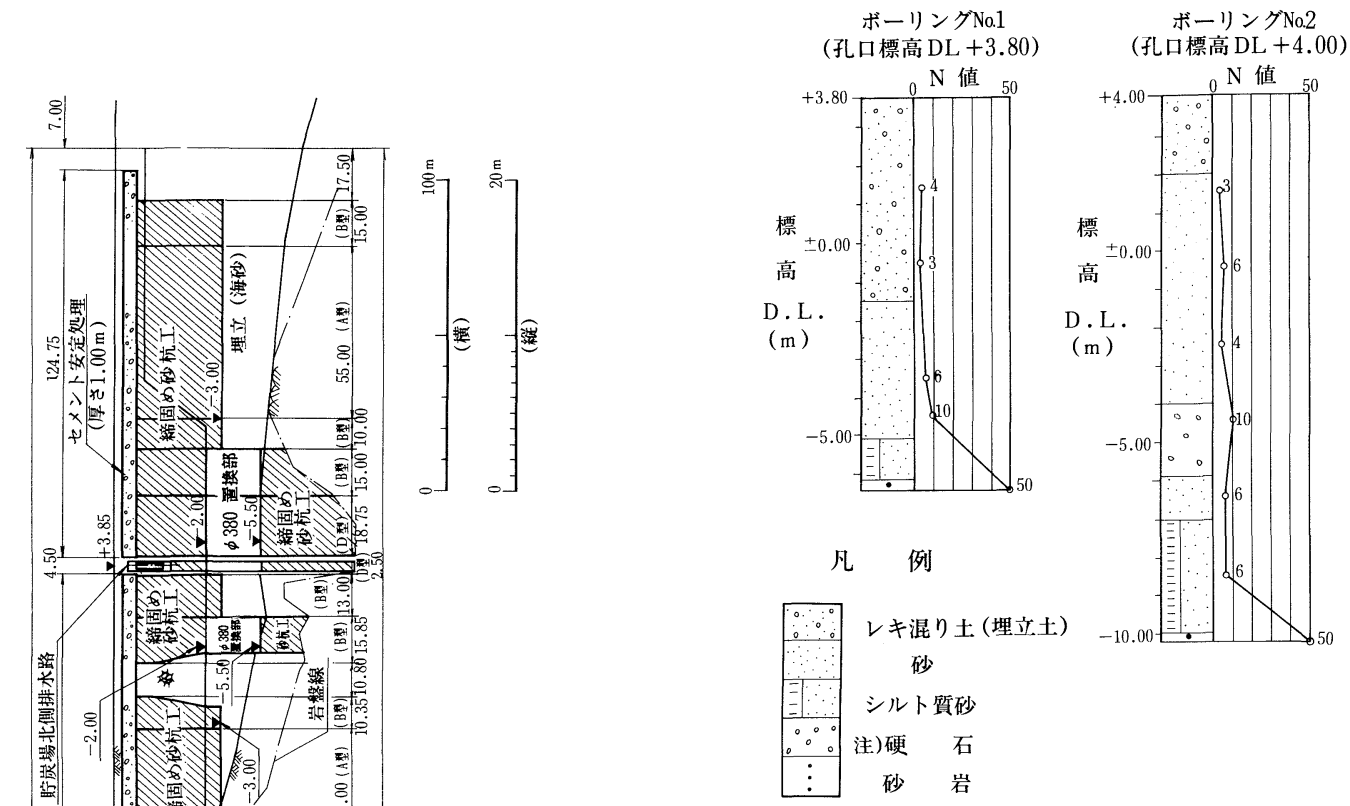

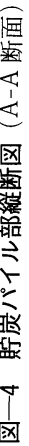
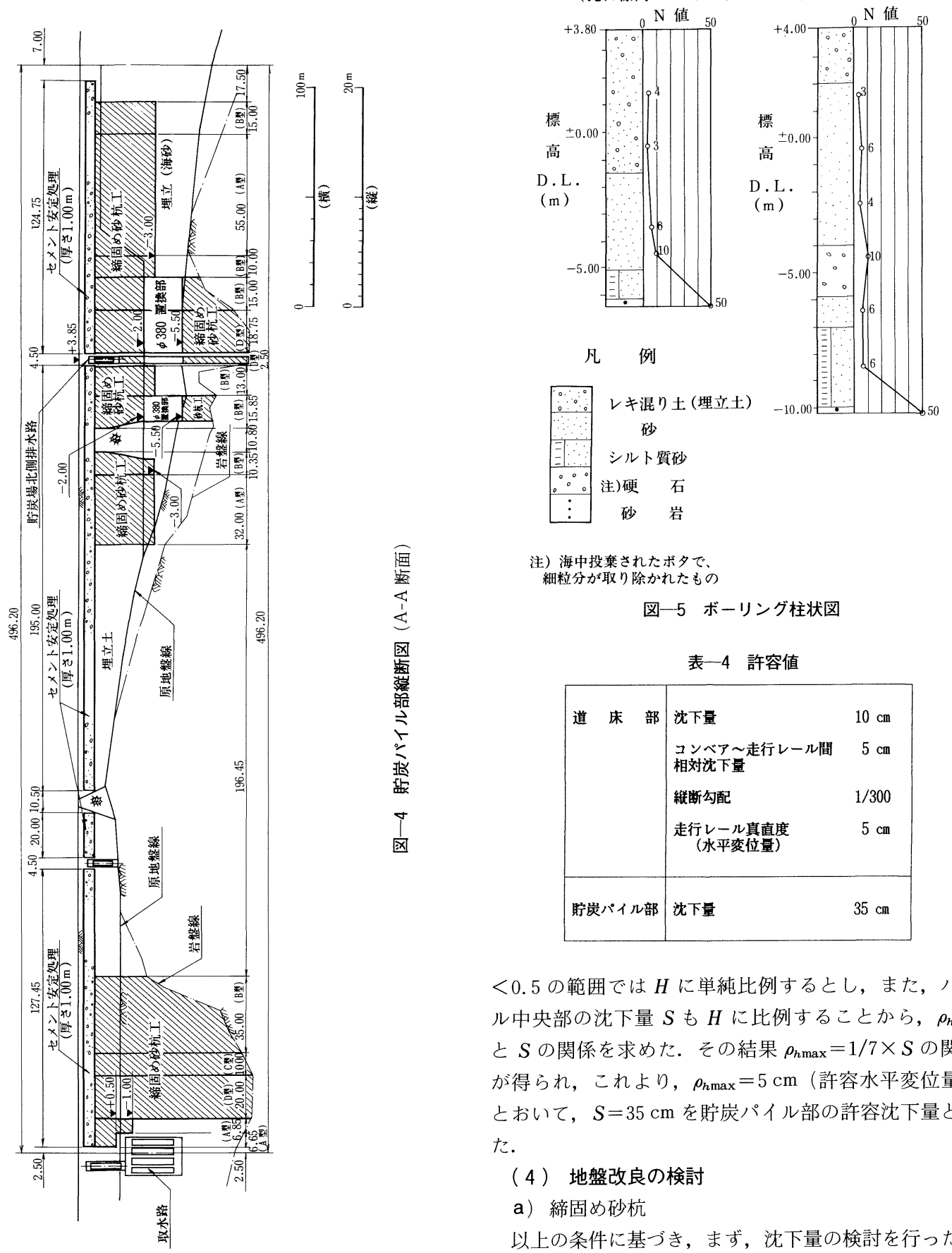

注）海中投棄されたボ夕で、

細粒分が取り除かれたもの

\begin{tabular}{|c|c|c|}
\hline & 表一4 許容值 & \\
\hline 道 床 部 & $\begin{array}{l}\text { 沈下量 } \\
\text { コンベア〜走行レール間 } \\
\text { 相対沈下量 } \\
\text { 䋖断勾配 } \\
\text { 走行レール真直度 } \\
\text { (水平変位量) }\end{array}$ & $\begin{array}{r}10 \mathrm{~cm} \\
5 \mathrm{~cm} \\
1 / 300 \\
5 \mathrm{~cm}\end{array}$ \\
\hline 眝炭パイル部 & 沈下量 & $35 \mathrm{~cm}$ \\
\hline
\end{tabular}

$<0.5$ の範囲では $H$ に単純比例するとし，また，パイ ル中央部の沈下量 $S$ も $H$ に比例することから， $\rho_{h \max }$ と $S$ の関係を求めた. その結果 $\rho_{h \max }=1 / 7 \times S$ の関係 が得られ，これより， $\rho_{h \max }=5 \mathrm{~cm}$ (許容水平変位量) とおいて,$S=35 \mathrm{~cm}$ を貯炭パイル部の許容沈下量とし た。

\section{（4）地盤改良の検討}

\section{a) 締固め砂杭}

以上の条件に基づき，まず，沈下量の検討を行ったと ころ, 軟弱層の比較的厚い部分では, 原地盤のままでは 許容沈下量を越えてしまうため, 沈下量の低減を目的亡 した地盤改良が必要となった。

改良工法としては，プレローディング・サンドドレー ン併用工法, 動圧密工法, 深層混合処理工法, 締固め砂 杭工法の 4 工法を比較検討したが, 工期, 経済性, 施工 
の確実性, 改良効果等を総合的に判断し, 締固め砂杭工 法を採用することとした。

原地盤の沈下計算ならびに締固め砂杭の必要改良率の 算定にあたっては，表一3に示されるよう，埋立土中の 流用土およびぼたが広範囲の粒度分布をもつかなり不均 一な材料であること，砂質土と分類される部分であって もかなりの細粒分を含んでいること，また，ぼたは水浸 により粘土化していく場合があると報告されている3 こ と等を考慮して, これらを粘性土として取り扱うことと した.

沈下計算は，埋立土（ぼた，流用土）層および在来の 粘性土層については，圧密試験により $e \sim \log p$ 曲線を 求め, 下に示す式 $(1)$ を用いて沈下量を求めた.

一方, 埋立土（海砂, 硬石) 層および在来の砂質土層 については, ドビアの式 (式 $(2))$ を用いて, 即時沈 下量として求めた.

$$
\begin{aligned}
& S_{c}=\frac{e_{0}-e}{1+e_{0}} \cdot H \\
& S_{s}=0.04 \frac{P_{0}}{N} \cdot H \cdot \log _{10} \frac{P_{2}}{P_{0}}
\end{aligned}
$$

ここに, $S_{c}$ : 粘性土の圧密沈下量 $(\mathrm{m})$

$S_{s}$ : 砂質土の即時沈下量 $(\mathrm{m})$

$e_{0}$ : 初期間隙比

$e:$ 間隙比

$H:$ 圧密される層の厚さ $(\mathrm{m})$

$N: N$ 值

$P_{0}$ : 載荷前における初期応力 $\left(\mathrm{tf} / \mathrm{m}^{2}\right)$

$\Delta P:$ 上載荷重 $\left(\mathrm{tf} / \mathrm{m}^{2}\right)$

$P_{2}:$ 載荷後の有効応力 $\left(P_{0}+\Delta P\right)\left(\mathrm{tf} / \mathrm{m}^{2}\right)$

道床部, 貯炭パイル部のそれぞれで, 上式により, 対 象となる圧密層の厚さごとに沈下量を計算し，それらを 許容沈下量以内に抑えるために必要な沈下低減係数を求 めた。この沈下低減係数 $\beta$ は, 締固め砂杭工の場合, 次式により表わされている.

$$
\beta=\frac{1}{1+(m-1) a_{s}} \text {. }
$$

ここに, $m$ : 応力分担比

$$
a_{s}: \text { 改良率 }
$$

これより, 応力分担比を一定とすれば, 所要の沈下低 減係数を得るための改良率 $a_{s}$ を定めることができる.

当地点においては, 先に行った護岸工事の締固め砂杭 による地盤改良部の計測結果より, 改良地盤の沈下量の 実測值 $S_{m}$ と, 原地盤の最終圧密沈下量の計算値 $S_{c}$ を 比較して， $m=2 \sim 8$ (このとき $a_{s}$ は 0.5) という結果 を得ている ${ }^{2)}$.

貯炭場の締固め砂杭の設計においては,この計測結果 と,ならびに既往の実測例より $a_{s} \leqq 0.3$ で $m$ の平均值
が 3.9 であるという報告 ${ }^{5)}$ 等を考慮して， $a_{s}$ が 0.5 か ら 0.2 の範囲で $m=3$ とすることとした.

$m=3$ とおいて, 式 ( 3 ) により, 所要の沈下低減係 数に対応する必要改良率を求め, 圧密層の厚さに応じた 改良率を定め, 砂杭の施工範囲を決定した.

改良率は，0.2，0.3，0.4，0.5の4 種類とした。

なお，図一4の縦断図に示すように，中間の海砂層を 打ち抜いて, さらにその下部にある在来軟弱層を改良す る必要のある部分については, 中間層部では $\phi 700 へ の$ 拡径, 締固めは行わないものとし, ケーシング径 $\phi 380$ の部分を砂で置換した。

図一6に，締固め砂杭による改良範囲を示す.

b) セメント安定処理

積上げ高さ $16 \mathrm{~m}$ の石炭パイルの安定については, 円 形すべり面法による検討を行い, 規準安全率 $F_{s} \geqq 1.3$ とした。この結果, 締固め砂杭による地盤改良だけでは 所要の安全率が得られないため, 基礎地盤の表層部にセ メント安定処理による地盤改良を行うこととした。

この表層セメント安定処理の設計強度, 改良厚さ, 改 良範囲の決定にあたっては, 円形すべり計算と弾性床上 のスラブとしての検討を行った。

図一7にセメント安定処理による固化盤の設計フローを示す.

円形すべり計算はフェレニウス法により行い，検討断 面は軟弱層の厚いA 貯炭パイル部とし, 最も危険なケー スとして, 貯炭パイルの長手方向への石炭のり面のすべ りを検討した. 粘着力 $C=16 \mathrm{tf} / \mathrm{m}^{2}$ の場合, 厚さ $0.5 \mathrm{~m}$ で $F_{s}=1.09$, 厚さ $1.0 \mathrm{~m}$ で $F_{s}=1.32$, 厚さ $1.5 \mathrm{~m}$ で $F_{s}=1.46$ であった.

図一7 の中で, 円形すべり計算により求めた必要粘着 力 $C=16 \mathrm{tf} / \mathrm{m}^{2}$ に対し, このときのセメント安定処理に よる固化盤の必要一軸圧縮強度 $q_{u}$ は, 文献 6), 7 ) 等 を参考に安全側を考慮して,$C=1 / 6 q_{u}$ の関係を仮定し て求めたものである.また， $k_{0}=2.4 \mathrm{kgf} / \mathrm{cm}^{3}$ は原地盤

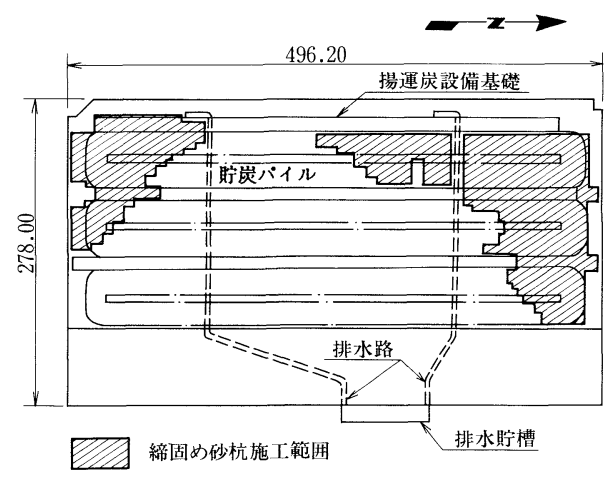

図一6 締固め砂杭施工範囲平面図 


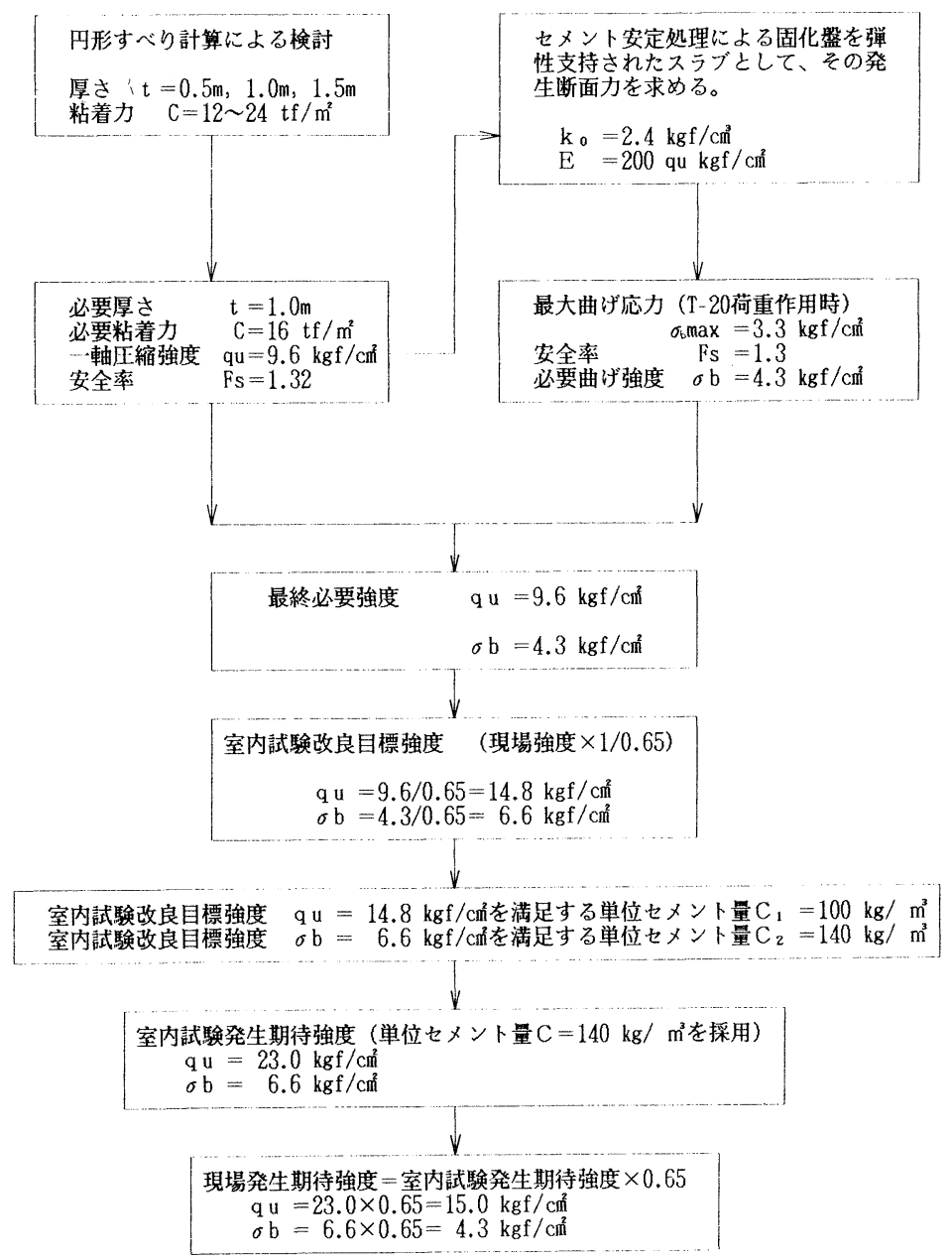

図一7 セメント安定処理による固化盤の設計フロー図

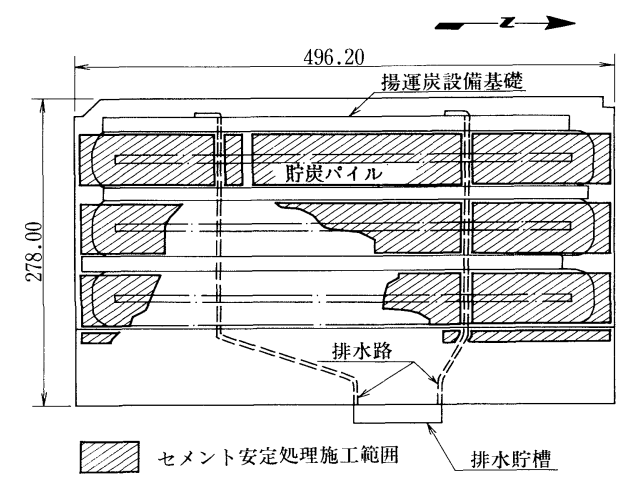

図一8 セメント安定処理施工範囲平面図

の平板載荷試験より求めたものであり, $E=200 q_{u}$ は文 献 6)，8）を参考に定めたものである. また, 現場強度 之室内強度の比 0.65 については, 文献 $9 ）$ によった.

図一 8 に，セメント安定処理の施工範囲を示す.

\section{3. 施 I}

\section{（1）締固め砂杭}

締固め砂杭による改良面積は, $28400 \mathrm{~m}^{2}$, 砂杭本数 21900 本，砂杭延長は $196000 \mathrm{~m}$ (このほかに申380の 砂置換部として $18900 \mathrm{~m}$ を施工）であった.

砂杭径は, 陸上工事の実績から最も標準的であると考 えられる $\phi 700$ とし, 砂杭の造成方法は, ケーシングの 引上げと貫入を交互に行う「突固め方式」とした.

施工機械は 7 台投入し，厚さ $50 \mathrm{~cm}$ のサンドマット $16000 \mathrm{~m}^{3}$ の施工も含めて, 約 6 か月で完了した.

護岸工事で行ったチェックボーリングでは, すべての データで砂杭の深さ $5 \mathrm{~m}$ ごとの平均 $N$ 值で 15 以上とい う結果を得ており, 十分安定した品質の砂杭が施工でき ていると判断されたので, 同品質の砂を使用し, 同一の 突固め方式および自記記録による打設状況の管理を行う ことを条件として, 貯炭場ではチェックボーリングの本 
数を砂杭約 440 本に 1 孔（総数 50 孔）とした.

図一9に貯炭場での砂杭施工深度と $N$ 值の関係を示 す。図中の実線は，護岸工事の実績における全チェック ボーリングの結果を平均したものであり，ほぼ同様の傾 向を示していることがわかる。

また, 盛上りについて, 表 5 に示す結果を得た。

( 2 ） セメント安定処理

セメント安定処理による改良面積は $51300 \mathrm{~m}^{2}$ であっ た。

改良の対象となる表層部には，埋立てたぼたと流用土 が混合された部分，ならびにそれらに対して締固め砂杭 を施工したことにより，砂が混入され盛上った部分（盛 上り土と称する）が存在した，後者については，改良率 の大きいところほど砂分を多く含むものとなっている.

セメント安定処理の施工は，スプレッダにてセメント を散布し，混合はスタビライザー（攪䢁幅 $2.0 \mathrm{~m} ）$ にて 行い，その走行速度は $2.0 \mathrm{~m} /$ 分を標準とし，転圧は夕 イヤローラ $(13 \mathrm{t})$ で 8 回, マカダムローラ $(10 \mathrm{t})$ で 2 〜4回とした.また，転圧効果が十分下部まで行きわた るよう, 厚さ $1 \mathrm{~m}$ の安定処理盤を 3 層 (下層 $40 \mathrm{~cm}$, 中 層 $30 \mathrm{~cm}$ ，上層 $30 \mathrm{~cm}$ ）に分けて施工するものとした. すなわち，設計天端より $60 \mathrm{~cm}$ 下がったところまで掘削 し，まず下層を仕上げ， $30 \mathrm{~cm}$ 分の土をまき出して中層， 同様にして上層という手順で施工した。

施工管理方針を決定するため，本施工に先立って室内 試験および現場試験施工を行い，以下のことが明らかに

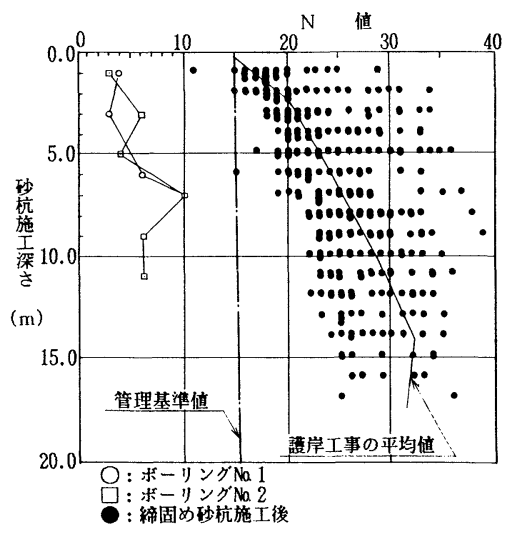

図一9 砂杭施工深さと $N$ 值

表一5 盛上りデータ

\begin{tabular}{|c|c|c|}
\hline 改良面榬 & $28,400 \mathrm{~m}^{2}$ & 杪杭体皘 \\
\hline 盛上り影㛙戦囲 & $45,800 \mathrm{~m}^{2}$ & 全盛上り土量 $37,136 \mathrm{~m}^{3}$ \\
\hline 平均秒杭長 & $8.9 \mathrm{~m} /$ 本 & 改良域内 \\
\hline 平均改良率 & $33.8 \%$ & 全平均盛上り高 $0.81 \mathrm{~m}$ \\
\hline
\end{tabular}

なった。

(1) 一軸圧縮強度の材令による強度増加について

材令 28 日と材令 7 日の一軸圧縮強度の比較を図一 10 に示す。これより，28 日強度は 7 日強度の $1.5 \sim 2.0$ 倍 の範囲にあり， $q_{u 28} \geqq 1.5 \times q_{u 7}$ の関係が成立する.

(2) 含水比, 乾燥密度と一軸圧縮強度の関係について 室内試験において，図一11に示すように，ぼたおよ び盛上り土の含水比をそれぞれ一定として乾燥密度の異 なる供試体を作成し，一軸圧縮試験を行った。この結果 より，材令 7 日の設計基準強度，すなわち， $q_{u 28}(23$ $\left.\mathrm{kgf} / \mathrm{cm}^{2}\right) \times 1 / 1.5=15 \mathrm{kgf} / \mathrm{cm}^{2}$ を満足する乾燥密度と含 水比の組合せの下限の境界線が得られる。一方，図一12
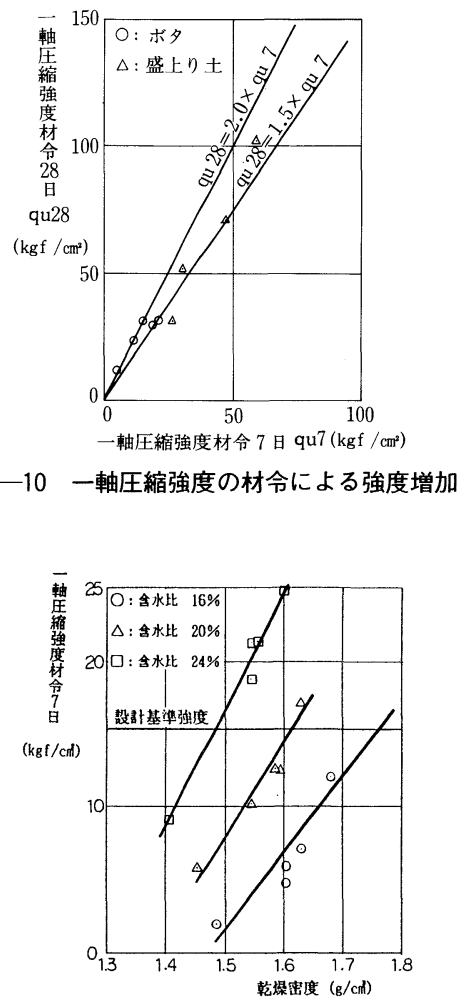

(a) ぼた

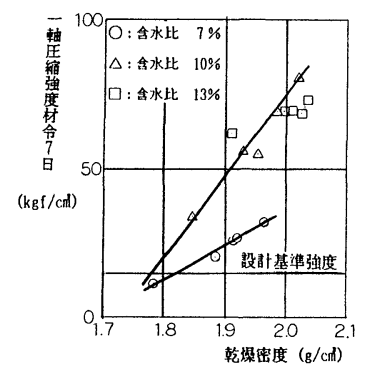

(b) 盛上り土

図一11 乾燥密度と圧縮強度の関係 


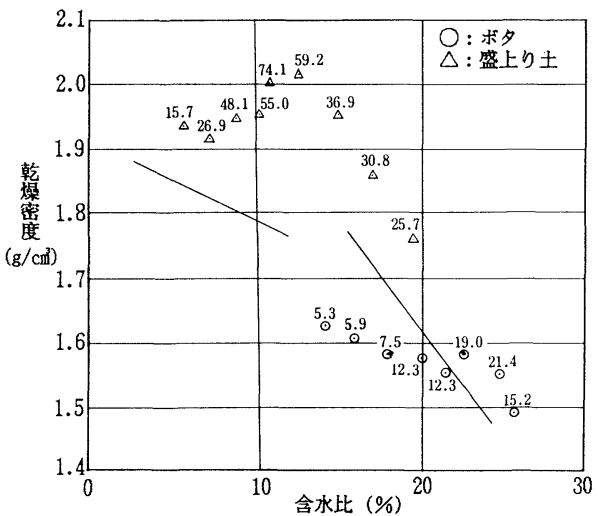

図一12 乾燥密度と含水比の関係

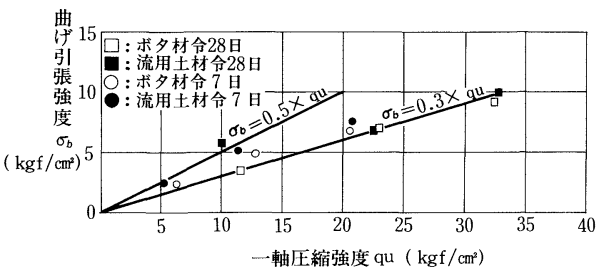

図-13 一軸圧縮強度と曲げ引張強度の関係

は種々の含水比に対して JIS 第 1 法により突き固めた 供試体の乾燥密度との関係をプロットしたものであり， 図中の数字は $q_{u 7}\left(\mathrm{kgf} / \mathrm{cm}^{2}\right)$ を示す。ここで，図中の 実線は図一11より得られる境界線を表わしており，こ れより，設計基準強度を満足するためには，含水比と乾 燥密度がこの線を越えるような施工を行うことが必要で あることがわかった。

(3) 曲げ引張強度について

一軸圧縮強度と曲げ引張強度の関係を図一13に示す. これによれば，曲げ引張強度は一軸圧縮強度の 0.3 0.5 倍の範囲にあり, $\sigma_{b} \geqq 0.3 \times q_{u}$ の関係が成立するも のと考えられる.

以上の結果より，現場施工管理を以下に述べる方針で 行うこととした.

・一軸圧縮強度が現場発生期待強度である $15 \mathrm{kgf} / \mathrm{cm}^{2}$ を満足すれば，上記(3)により，曲げ引張強度も 4.5 $\mathrm{kgf} / \mathrm{cm}^{2}$ 以上であると判断できる.また，上記(1)の $q_{u 28} \geqq 1.5 \times q_{u 7}$ の関係より, $q_{u 7} \geqq 10 \mathrm{kgf} / \mathrm{cm}^{2}$ であれ ば良いと判断できる。したがって，セメント安定処理 による固化盤の品質管理を行ううえで最も重要である 強度管理は，主として材令 7 日の一軸圧縮強度試験に より行うものとする.

・上記(2)により, 現場含水比が低い場合は, 散水を行っ て含水比を高めるものとし, 含水比と乾燥密度の組合 せとして，図一12 中の境界線に近づけるようにする.
表一 6 品質管理項目

\begin{tabular}{|c|c|c|}
\hline 項 & 頻 & 方 \\
\hline $\begin{array}{l}\text { 贪水比、 } \\
\text { 乾爆密度 }\end{array}$ & 施工日每 & $\begin{array}{l}\text { 「置換法による土 } \\
\text { の密度試験方法」 } \\
\text { JIS A } 1214\end{array}$ \\
\hline $\begin{array}{r}\text { 一軸圧縮強度 } \\
\text { (材令 7日) } \\
\text { (材令28日) }\end{array}$ & $\begin{array}{l}2000 \mathrm{~m}^{3} \text { K } 1 \text { 回 } \\
6000 \mathrm{~m}^{3} \text { } 1 \text { 回 }\end{array}$ & $\begin{array}{l}\text { 「アスファルト鋪装 } \\
\text { 要絧」セメント安 } \\
\text { 処理工の一軸圧縮強 } \\
\text { 度試験方法に準じた }\end{array}$ \\
\hline 曲げ引張強度 & $5000 \mathrm{~m}^{2} に 1$ 回 & $\begin{array}{c}\text { 「コンクリートの曲 } \\
\text { げ強度鹉験方法」 } \\
\text { JIS A } 1106\end{array}$ \\
\hline
\end{tabular}

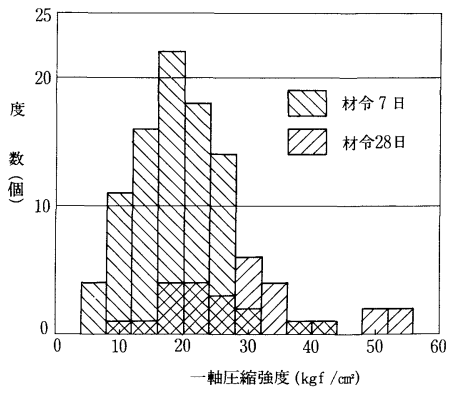

図一14 一軸圧縮強度試験結果

ただし，これについては，現場での改良対象土が平 面的にもかなり不均一であり，細かい含水比の数值管 理を行うことは，工程ならびに経済性の面で難しいこ とから，1日の施工対象範囲に対して，おおよその目 安で行ったにすぎない.

品質管理の項目，測定頻度，方法を表-6に示す.

一軸圧縮強度の管理基準としては，コンクリートに 準じた考え方をとり，

・試験值は設計基準強度の $80 \%$ を $1 / 20$ 以上の確率で 下回らないこと, かつ, 設計基準強度を $1 / 4$ 以上の確 率で下回らないこと，とした。

現場での一軸圧縮試験の結果は図一14に示すとおり であり，平均值は材令 7 日で $18.6 \mathrm{kgf} / \mathrm{cm}^{2}$ ，材令 28 日 で $29.2 \mathrm{kgf} / \mathrm{cm}^{2}$ であった. 改良の対象となる土質材料 が不均一であること，また，日々の含水比が変動するこ と等が原因と考えられるが，強度のばらつきは大きい. なお，現場で行った一軸圧縮試験の供試体は，セメント 混合処理後の材料を採取し，モールド内に JIS 第 1 法 によって突き固めたものである.モールドによる $q_{u}$ と コアカッターにより採取した供試体による $q_{u}$ との比較 を行い，モールド供試体の強度が，十分現場強度を反映 していると判断した。

また, 施工完了後, 気泡ボーリング 12 本 $(6$ か所 $\times 2$ 本 $)$ によりサンプリング，三軸圧縮試験および一軸圧縮試験 を行ったが， $C_{u}$ が $2.5 〜 5.8 \mathrm{kgf} / \mathrm{cm}^{2}$ (平均 $3.4 \mathrm{kgf}$ / $\mathrm{cm}^{2}$ ), $q_{u}$ が $11.1 \sim 38.8 \mathrm{kgf} / \mathrm{cm}^{2}$ (平均 $20.5 \mathrm{kgf} / \mathrm{cm}^{2}$ ) 
であった。これらの值もモールドによる $q_{u}$ と同じく大 きなばらつきを示しており，また， $q_{u}$ の平均值はモ一 ルドによる値よりも小さな值となっているが，これには サンプリング時の乱れの影響もあると考えられる.

以上の結果を総合すると，ばらつきは大きいものの， 全体としては十分な強度を有するセメント安定処理によ る固化盤が得られていると判断できる.

\section{4. あとがき}

松浦火力発電所貯炭場における地盤改良の設計・施工 の概要について述べた．現時点では，まだ石炭が搬入さ れていないが, 搬入，載荷後には貯炭パイル部および道 床部の変位量を測定し, 計算值との比較, 確認を行う予 定である.

\section{参 考 文 献}

1）篠原淑郎・村 良平・沢田 隆：松浦火力発電所新設工 事締固め砂杭による地盤改良について (その 1$)$, 電力土 木, 1987 年 1 月.
2）篠原淑郎・沢田 隆・井筒庸雄：松浦火力発電所新設工 事締固め砂杭による地盤改良について (その 2), 電力土 木, 1987 年 5 月.

3) 山内豊聡：九州・沖縄の特殊土, 九州大学出版会, 1983 年.

4）西 好一 - 江刺靖行 - 吉田保夫 - 島本正雄 : 大型送電用 鉄塔基礎杭に及ぼす地盤変形の影響, 電力中央研究所報 告 $381006, p p .31,1981$ 年.

5）網干寿夫ほか：軟弱地盤におけるサンドコンパクション 工法および深層混合工法の問題点, 土木学会誌, Vol. 67 増刊, 1982 年.

6）島光照雄 : セメント系材料による安定処理土の強度定数, セメント技術年報, No. 34,1980 年.

7) 片岡宏治・後藤年芳・万仲茂：セメント系材料を用い た固化処理土の三軸圧縮性状, セメント技術年報, No. 36, 1982 年.

8）寺師晶明ほか：深層混合処理工法における杭状改良地盤 の支持力および圧密特性, 港湾技研報告, 第 22 巻, 第 2 号, 1983 年 6 月.

9）セメント系固化材による地盤改良マニュアル, セメント 協会, pp. 52, 1985 年.

(1989.11.24 • 受付) 